\title{
Broadcasting Grass Seed to Revegetate Sandy Soils
}

\author{
ERIC KOCHER AND J. STUBBENDIECK
}

\section{Abstract}

This study was conducted to determine the effects of tillage, irrigation levels, seed coating rates and species on grass establishment. Sand bluestem [Andropogon gerarditi var. paucipilus (Nash) Fern.] and little bluestem [Schizachyrium scoparium (Michx.) Nash] seeds were coated with a lime and nutrient slurry at 3 rates and broadcast on abandoned cropland in the Nebraska Sandhills. A mixture of noncoated switchgrass [Panicum virgatum L.] and sand lovegrass [Eragrostis trichodes (Nutt.) Wood] was also broadcast. Three levels of irrigation were applied during the seeding year. Seedling establishment was higher on the disked areas than on nontilled areas. Establishment increased as irrigation level increased. Establishment of sand bluestem and little bluestem were similar, while establishment of the switchgrass-sand lovegrass mixture was less. Under the conditions of this experiment, seed coating rate had no influence on establishment.

Development of land in the Nebraska Sandhills for row crop cultivation under center-pivot irrigation became a common practice during the 1970's. In the past few years, many marginal sites have been abandoned, leaving large areas of exposed sand. Revegetation of these sites is necessary to prevent extensive soil movement and expansion of these areas and to return them to productive land.

Drilling has been the most effective method of planting grass seed (Hyder et al. 1955, Eckert and Evans 1967). However, aerial seeding may cover larger areas in a relatively short time at low cost (Killough 1950).

Several important native grasses of the Sandhills Prairie have fluffy seed. Broadcasting this type of seed resulted in uneven distribution (Killough 1950). Seed distribution was improved by coating the seed prior to seeding (Stewart 1949), but seed coating was shown to reduce germination (Scott 1975). Soil moisture is critical to seedling establishment, and, as a result, supplemental irrigation improved grass establishment (Campbell and Swain 1973).

This study was initiated to determine the effects of tillage, irrigation levels, seed coating rates, and species on grass establishment in the Nebraska Sandhills.

\section{Materials and Methods}

The study site is located near the northern border of Custer County, Nebraska. Ipage loamy fine sand (mixed, mesic Aquic Ustipsamment) occupies about two-thirds of the study area. Valentine fine sand (mixed, mesic Typic Ustipsamment) occupies the remaining one-third. The topography is level to slightly rolling.

Growing season extends from early May to the middle of September. Average annual precipitation is $55 \mathrm{~cm}$, with about $80 \%$ occurring between 1 April and 30 May (NOAA 1981). Climax vegetation is primarily a mixture of native tall, mid-, and shortgrass prairie species along with other species of plants adapted to sandy soils (Keeler et al. 1980).

Eighty hectares of rangeland were plowed, a well was drilled, and a center pivot irrigation system was placed on the field in 1971 . The land was used to produce corn [Zea mays $L$.] for 10 years. Crop production levels were unacceptable, and the decision was made to revegetate the area with native grasses. Sudangrass [Sorghum vulgare Pers.] was grown on the land in 1981, the year

\footnotetext{
Authors are former graduate research assistant and professor (range ecology), Department of Agronomy, University of Nebraska, Lincoln 68583, respectively. Eric Kocher is currently graduate assistant, Department of Agricultural Economics, Oklahoma State University, Stillwater 74074.

Published as Paper Number 7840, Journal Series, Nebraska Agricultural Experiment Station.

Manuscript accepted 17 February 1986.
}

prior to initiation of the study.

Treatment design was a split-split plot with tillage as the whole plot, irrigation as the sub-plot, and seeding treatment on the subsub plot treatment. Tillage consisted of shallow disking or no tillage. Plots were disked with a tandem double disk 1 day prior to seeding. A residue of forage sorghum with a height of about $25 \mathrm{~cm}$ remained on the untilled plots. Experimental design for irrigation was a randomized complete block with 2 replications.

The nozzles on the irrigation system were changed to apply water treatments in concentric circular bands. Bands were $60 \mathrm{~m}$ in width and received a total of either 0,2 , or $4 \mathrm{~cm}$ of supplemental water. These bands were arranged as a randomized complete block with 2 replications as sub-plots of the tillage treatments. Water was applied in 3 equal amounts from 15 to $17 \mathrm{July}, 21$ to $22 \mathrm{July}$, and 27 to 29 July. The irrigation schedule was based on moisture stress. Precipitation during the growing season of 1982 was $36 \mathrm{~cm}$.

Seven seeding treatments were applied as sub-sub plots of the tillage by irrigation treatments. Each sub-sub plot was $18 \mathrm{~m}^{2}$ in size. 'Goldstrike' sand bluestem [Andropogon gerardii var. paucipilus (Nash.) Fern.] and 'Cimmarron' little bluestem [Schizachyrium scoparium (Michx.) Nash] seeds were coated with a mixture of $82.0 \%$ lime, $9.0 \%$ phosphoric acid, $5.4 \%$ sulfur, $2.0 \%$ ammoniacal nitrogen, $1.3 \%$ zinc, and $0.3 \%$ iron. Seed was coated at heavy, light, and zero application rates (Table 1). An additional seeding

Table 1. Seeding rate (total seeds/0.1 $\mathrm{m}^{2}$ ) and pure live seeds $/ 0.1 \mathrm{~m}^{2}$ ) and germination percentage of grass species seeded in 1982.

\begin{tabular}{|c|c|c|c|c|}
\hline \multirow[b]{2}{*}{ Species } & \multirow{2}{*}{$\begin{array}{l}\text { Seed Coating } \\
\text { Rate } \\
\text { (coating weight): } \\
\text { seed weight) }\end{array}$} & \multirow{2}{*}{$\frac{\text { Germination }}{\%}$} & \multicolumn{2}{|c|}{ Rateof Seeding } \\
\hline & & & $\begin{array}{l}\text { Total seeds } \\
\text { per } 0.1 \mathrm{~m}^{2}\end{array}$ & $\begin{array}{c}\text { Pure live seeds } \\
\text { per } 0.1 \mathrm{~m}^{2}\end{array}$ \\
\hline $\begin{array}{l}\text { Sand } \\
\text { bluestem }\end{array}$ & $\begin{array}{l}0.0: 1.0 \\
1.0: 1.0 \\
2.3: 1.0\end{array}$ & $\begin{array}{l}73 \\
73 \\
73\end{array}$ & $\begin{array}{l}32 \\
32 \\
39\end{array}$ & $\begin{array}{l}23 \\
23 \\
28\end{array}$ \\
\hline $\begin{array}{l}\text { Little } \\
\text { bluestem }\end{array}$ & $\begin{array}{l}0.0: 1.0 \\
0.7: 1.0 \\
1.4: 1.0\end{array}$ & $\begin{array}{l}52 \\
52 \\
52\end{array}$ & $\begin{array}{r}72 \\
75 \\
116\end{array}$ & $\begin{array}{l}37 \\
39 \\
60\end{array}$ \\
\hline $\begin{array}{l}\text { Mixture: } \\
\text { Switchgrass } \\
\text { Sand } \\
\text { lovegrass }\end{array}$ & & 86 & 27 & 23 \\
\hline
\end{tabular}

treatment was a mixture of 'Pathfinder' switchgrass [Panicum virgatum L.] and 'Nebraska 27' sand lovegrass [Erogrostis trichoides (Nutt.) Wood]. Rates of seeding for all treatments are presented in Table 1. Seeds were broadcast by hand from 11 to 13 May 1982. Rain fell at the study site on 10,11, 13, 19, 20, and 24 May 1982. Consequently, all of the plots received rain following seeding. Total precipitation during May 1982 was $14 \mathrm{~cm}$. Experimental design for seeding treatments was a completely randomized design with 24 replications.

Seedling density was measured on 24 and 25 September 1982. Seven $0.1-\mathrm{m}^{2}$ frames were randomly placed within each plot and the numbers of seedlings were recorded. Seedling density measurements were collected again on 7 June 1983 and on 15 August 1983. The data were subjected to analysis of variance.

Since the treatments were seeded at different rates (Table 1), the 
data were standardized by determining percentage establishment before the analysis was performed. Establishment was determined by dividing seedling density (seedlings $/ 0.1 \mathrm{~m}^{2}$ ) by seeding rate (pure live seed $/ 0.1 \mathrm{~m}^{2}$ ) and multiplying this value by 100 . Seedling density was assumed to possess a Poisson distribution (Personal communication, Kent Eskridge, Department of Biometrics, University of Nebraska-Lincoln). Since analysis of variance assumes that data for the dependent variables are normally distributed, the data for seedling density were normalized by adding 0.5 to the recorded values for each frame and taking the square root of this number (Steel and Torrie 1980).

Under the conditions of this experiment, an establishment rate of over $4 \%$ on the last sampling date was projected to become a satisfactory stand. This level of establishment would not only provide erosion protection, but it would also provide forage to grazing livestock during the third growing season (1984) after seeding.

\section{Results and Discussion}

\section{Tillage}

Disking prior to broadcasting resulted in higher seedling survival for all 3 data collection periods (Table 2). Surface litter on

Table 2. Establishment (\%) of seeded species for two tillage treatments during 1982 and 1983.

\begin{tabular}{lccc}
\hline & \multicolumn{3}{c}{ Sampling date } \\
\cline { 2 - 4 } Tillage treatment & September, 1982 & June, 1983 & August, 1983 \\
\hline \multirow{2}{*}{ Disk } & $6.0 \mathrm{a}^{*}$ & $5.0 \mathrm{a}$ & $5.1 \mathrm{a}$ \\
No-till & $3.8 \mathrm{~b}$ & $3.3 \mathrm{~b}$ & $3.6 \mathrm{~b}$ \\
\hline
\end{tabular}

*Means within a column followed by different letters are significantly different at the .05 level of probability.

untilled land was abundant and prevented many of the broadcasted seeds from reaching the soil surface and obtaining adequate soil contact. In contrast, disking incorporated surface litter into the soil and removed or reduced the initial barrier that prevented seed from reaching the soil. Disking altered the microrelief, which improved seed contact with the soil. It was observed that disking also provided early control of field sandbur [Cenchrus longispinus (Hack.) Fern.], which was the most abundant weed. This may have reduced competition enough to improve seedling growth and survival.

\section{Irrigation}

Irrigation increased seedlng establishment (Table 3). Irrigation
Table 3. Establishment $(\%)$ of seeded species for three irrigation rates during 1982 and 1983.

\begin{tabular}{lccc}
\hline \hline & \multicolumn{3}{c}{ Sampling date } \\
\cline { 2 - 4 } Irrigation treatment & September, 1982 & June, 1983 & August, 1983 \\
\hline \multirow{2}{*}{ Zero } & & $-\%$ & \\
Low & 4.4 & 3.8 & 3.9 \\
High & 4.9 & 4.2 & 4.4 \\
Linear contrast & 5.5 & 4.6 & 4.7 \\
\hline
\end{tabular}

*Significant at the .10 probability level.

comprised a small percentage of the total water received by the seedlings during 1982 (Table 4). Since a linear response did occur, timing of irrigation may have been equally or more important than total irrigation. Precipitation following seeding was above average (Table 4). If precipitation had been lower, irrigation probably would have been more critical to seedling establishment.

Addition of irrigation water may help to assure stand establishment during dry years. It also may be possible to reduce seedling rates to help offset the cost of irrigation.

\section{Seedling Treatment}

Establishment of the 3 seeding treatments was different for all 3 data collection periods (Table 5). Establishment rates between

Table 5. Establishment (\%) of individual species during 1982 and 1983.

\begin{tabular}{lccc}
\hline & \multicolumn{3}{c}{ Sampling date } \\
\cline { 2 - 4 } Seeding treatment & September, 1982 & June, 1983 & August, 1983 \\
\hline & 5.5 & 4.3 & 4.4 \\
Little bluestem & 4.8 & 4.2 & 4.2 \\
Sand bluestem & & 3.2 & 3.3 \\
Switgrass-sand & 3.3 & 0.6 & 0.2 \\
lovegrass (mixture) & 0.9 & 0.6 & \\
LSD.05 &
\end{tabular}

sand bluestem and little bluestem were not different for all 3 data collection periods. Establishment of both sand bluestem and little bluestem was higher than establishment of the switchgrass-sand lovegrass mixture. Sand bluestem and little bluestem stands were adequate for erosion protection and forage production, but the switchgrass-sand lovegrass mixture was not.

Coating Rates

Establishment percentages for the different coating rates were

Table 4. Total monthly precipitation ( $\mathrm{mm}$ ) and departures from normal for January, 1982 through December, 1983, at Anselmo, Nebraska.1

\begin{tabular}{|c|c|c|c|c|c|}
\hline \multirow[b]{2}{*}{ Month } & \multicolumn{2}{|c|}{1982} & \multicolumn{2}{|c|}{1983} & \multirow[b]{2}{*}{ Normal $^{2}$} \\
\hline & Precipitation' & Departure & Precipitation & Depature & \\
\hline January & 11 & 0 & $-\mathrm{mm}$ & -7 & 11 \\
\hline February & 1 & -14 & 4 & -11 & 15 \\
\hline March & 22 & -13 & 95 & +60 & 35 \\
\hline April & 67 & +10 & 55 & -2 & 57 \\
\hline May & 140 & +52 & 131 & +43 & 88 \\
\hline June & 88 & -6 & 216 & +122 & 94 \\
\hline July & 22 & -69 & 114 & +23 & 91 \\
\hline August & 112 & +40 & 35 & -37 & 72 \\
\hline September & 17 & -35 & 27 & -25 & 52 \\
\hline October & 100 & +71 & 38 & +9 & 29 \\
\hline November & 56 & +37 & 84 & +65 & 19 \\
\hline December & 49 & +37 & 12 & 0 & 12 \\
\hline Annual & 685 & $\overline{+110}$ & $\overline{815}$ & $\overline{+240}$ & $\overline{575}$ \\
\hline
\end{tabular}


not different for any of the 3 data collection periods. The seed coating was highly soluble, and precipitation immediately following seeding was intense enough to wash the majority of the coating from the seed. As a result, any negative affect the coating may have had on seed germination was either greatly reduced or removed.

\section{Interactions}

The tillage by irrigation interaction was significant for 3 seeding treatments: only the little bluestem (August, 1983), sand bluestem and little bluestem (September, 1982), and little bluestem (September, 1982). The high irrigation treatment was the most sensitive to tillage treatment, since it resulted in the greatest increase in establishment between no tillage and disking. Higher seedling establishment on disked plots over no tillage for the low irrigation treatment was greater than, or equal to, the increase in establishment associated with the highest irrigation over no irrigation.

The tillage by seeding treatment interaction was significant for all sampling periods. Sand bluestem showed the greatest response to the pre-broadcast tillage treatment. If the area was disked before broadcasting, establishment of little bluestem plants increased more than did survival of the switchgrass-sand lovegrass mixture. The tillage by irrigation and seeding treatment interactions indicate that treatment responses were greater on disked areas than on untilled areas.

\section{Optimum Treatment Combination}

The combination of treatments which produced the highest seedling establishment was disking before planting, high level of irrigation, and little bluestem as the seeding treatment. Since establishment was not affected by coating rate, the lowest coating rate at which seed distribution would still be uniform would be the ideal coating rate.

\section{Conclusions}

Under conditions of this study, disking before broadcast seeding consistently resulted in greater establishment of the seeded species than did no tillage. While this was successful in this study, disking was not compared to any other methods of improving seed to soil contact. Other mechanical methods of seedbed preparation or seed incorporation by drilling may also be successful.
Linear contrasts were significant, which indicated a direct positive relationship between irrigation level and seedling survival. Total amount of water applied made up a small percentage of total water available during the growing season. The fact that a linear response did occur indicates timing of irrigation was important.

Differences in survival were found between seeding treatments. Survival of the switchgrass-sand lovegrass mixture was lower than the average survival of the little bluestem and sand bluestem treatments. Survival rates between sand bluestem and little bluestem were not different.

Survival rates for different coating rates were not different. However, the coating was washed off the seed by rain soon after broadcasting. Any effect the coating may have had on survival was removed by the rain. Distribution of the coated seed after broadcasting was uniform, therefore, the coating served its purpose.

Tillage by treatment interactions indicated a greater response to treatment levels in the disked plots. Therefore, treatment level selection for the treatments evaluated in this study is more important when the area to be seeded is disked than it is when untilled areas are seeded.

\section{Literature Cited}

Campbell, M.J., and F.G. Swain. 1973. Factors causing losses during the establishment of surface-sown pastures. J. Range Manage. 26:355-359.

Eckert, R.E., Jr., and R.A. Evans. 1967. A chemical-fallow technique for control of downy brome and establishment of perennial grasses on rangeland. J. Range Manage. 20:35-41.

Hyder, D.N., F.A. Sneva, and W.A. Sawyer. 1955. Soil firming may improve range seeding operations. J. Range Manage. 8:159-153.

Keeler, K.H., A.T. Harrison, and L.S. Vescio. 1980. The flora and sandhills prairie communities of Araphao Prairie, Arthur County, Nebraska. Prairie Natur. 12:65-78.

Killough, J.R. 1950. Reseeding the range by airplane. J. Range Manage. 3:33-41.

NOAA. 1981. Climatological data: Nebraska. Vol. 86. Nat. Oceanic and Atmospheric Admin., Washington, D.C.

Scott, D. 1975. Effects of seed coating on establishment. New Zealand J. Agr. Res. 18:59-67.

Steel, R.G.D., and Torrie, J.H. 1980. Principles and procedures of statistics. McGraw-Hill Book Co., New York.

Stewart, G. 1949. Range reseeding by airplane compared with standard ground methods. Agron. J. 41:283-288. 